Research Report No. 25/2008

\title{
Indigenous Self-Determination and the State
}

Shin Imai

Osgoode Hall Law School of York University, simai@osgoode.yorku.ca

Follow this and additional works at: http:/ / digitalcommons.osgoode.yorku.ca/clpe

\section{Recommended Citation}

Imai, Shin, "Indigenous Self-Determination and the State" (2008). Comparative Research in Law \& Political Economy. Research Paper No. $25 / 2008$.

http://digitalcommons.osgoode.yorku.ca/clpe/196 


\section{Comparative Research in Law \& Political Economy}

\section{Shin Imai}

Indigenous Self-Determination and the State

Forthcoming in Indigenous Peoples and the Law: Comparative and Critical Perspectives (Oxford: Hart Publishing, 2009)

EDITORS: Peer Zumbansen (Osgoode Hall Law School, Toronto, Director, Comparative Research in Law and Political Economy, York University), J ohn W. Cioffi (University of California at Riverside), Lindsay Krauss (Osgoode Hall Law School, Toronto, Production Editor) 

CLPE Research Paper 25/2008

Vol. 04 No. 05 (2008)

\title{
Shin Imai
}

\section{INDIGENOUS SELF-DETERMINATION AND THE STATE}

\begin{abstract}
The right of indigenous self-determination is now accepted at both the national and international level, but the exercise of the right to self-determination does not connote any specific institutional arrangement. This chapter, from the forthcoming book, Indigenous Peoples and the Law: Comparative and Critical Perspectives (Hart Publishing, Oxford), describes a variety of arrangements in Australia, Canada, New Zealand and the United States. Indigenous people have the greatest political autonomy in the sovereignty/self-government model found in the United States and in the latest self government agreements from Canada. The selfadministration/self-management model provides for indigenous entities to deliver social services and educational services to their own communities. The co-management/joint management model provides for indigenous participation in the management of lands and resources. Finally, there are arrangements that provide for participation in public government. An example would be the guaranteed Maori seats in the legislature in Aotearoa/New Zealand.
\end{abstract}

The chances of success for these initiatives are increased by ensuring that community member participate in the design and delivery. A scheme imposed from above will likely run into problems. During the period of implementation it is important to address issues relating to the identification of the appropriate group, the accountability of the indigenous institution to its own members and the role of women.

Keywords: Indigenous self-determination, self-administration, selfgovernment, co-management, tribal government, Aboriginal, Maori, Indian, Inuit, Metis. 
JEL classification: K39

\author{
Author Contact: \\ Shin Imai \\ Professor, Osgoode Hall Law School, York University \\ 4700 Keele St. Toronto ON, M3J 1P3 \\ Email: simai@osgoode.yorku.ca
}




\title{
INDIGENOUS SELF-DETERMINATION AND THE STATE
}

\author{
Shin Imai
}

\section{INTRODUCTION}

One of my clients in the mid-eighties was a First Nation located in northern Canada. To get to the reserve, I had to take a two-hour flight from Toronto to a small town by jet, stay over night, and board a connecting flight on an eight-person prop the next morning. The reserve was located on an island in the middle of the wilderness. There were no roads or railways within hundreds of miles. When the plane landed I could see nothing but a carpet of scrub broken only by the small paved landing strip and a dusty road heading off to the village. An invisible line separated provincial Crown land, where the landing strip was located, from federal Crown land, where the Indian reserve was located.

The elders of the community were concerned about a growing alcohol problem among the youth. Their worries came to a head when a young man was found frozen to death in the woods after drinking. After hearing from the elders, the Chief and Council enacted a law banning liquor on the reserve. There was a straightforward way to enforce the prohibition and stem the flow of alcohol. The only entry into the reserve was by plane, so it would be easy to search the luggage of the passengers, as the plane was unloaded. The First Nation asked the police constable who was stationed in the community to search the luggage of all the passengers and confiscate all liquor.

There was a legal problem with this idea. Because the plane landed on provincial land, only provincial law applied. The police constable, who was appointed by the Commissioner of the Ontario Provincial Police, was told by his superiors that he could search people's personal belongings only if there were reasonable and probable grounds that a crime was being committed. Possessing liquor was legal on provincial land. Therefore, when the person got off the plane, there was no crime, and there were no

* Osgoode Hall Law School, York University, Canada. 
grounds to perform a search. This meant that a search could only be conducted once the individual set foot on federal reserve land, where the possession of liquor was illegal. But there was a practical problem with this idea. There was no fence demarcating the boundary and there was no easy way to police the crossing of the invisible line between provincial and federal land.

The Chief was frustrated, and decided to appoint his own 'peacekeepers' from the First Nation to search all the passengers as they unloaded their luggage off the plane. Most passengers co-operated with the peacekeepers, but during one of these searches a community member objected to the search. A scuffle followed, and liquor was found in the community member's bag. It was confiscated and destroyed by the peacekeepers. No other action was taken against the individual. The community member, however, was outraged and complained to a legal aid clinic located in the nearest town, which was an hour and half away by air. The clinic lawyer felt that the search was illegal, as the search occurred on provincial land. Therefore, in the eyes of the law, the peacekeepers were no more than private citizens who had no right to search the belongings of other private citizens. The lawyer helped the community member lay a criminal information against the two peacekeepers, and they were charged with assault.

A variety of 'legal' work-arounds were canvassed to address this problem. The most obvious solution was to make sure that the airstrip was located on federal reserve land. The province, however, refused to transfer the airstrip to the federal government, and the federal government would not consider paying for a new airstrip on its own land. Another proposal was for the Band to construct a huge fence around the airstrip and force individuals to pass through a gate. Poets and cartoonists would immediately see the comic potential of constructing such a fence in the middle of a wilderness, to circumvent a problem created by an invisible and meaningless boundary. Some government lawyers, alas, had less of a sense of humour, and actually suggested the fence as an appropriate solution. Unfortunately, or fortunately, neither the federal nor the provincial government would pay for such a fence. In the end, the matter was never resolved. The charges against the individual peacekeepers were quietly dropped. The federal- provincial boundary has not changed, and the challenge of enforcing the prohibition on liquor continues.

Aboriginal communities across Canada have similar stories, featuring laws that are appropriate for urban areas in the south, but are 
imposed in ludicrous ways in the remote north. For example, Susan Drummond recounts a story of an Inuk youth who was tried by a judge in a city in the south for a violent crime. The judge's solution was to sentence the youth to return to his isolated northern community. The northern community was just as worried about the youth in their community and incarcerated him on his arrival. The southern judge ordered the youth released and threatened to have community members charged with kidnapping. ${ }^{1}$

In the two stories recounted above, the Criminal Code operated in a way that was counterproductive to community protection. In the first story, the Criminal Code helped protect the bootleggers by making prosecution and detection very difficult. In the second story, the mainstream justice system dealt with a problem youth in a southern community by moving him back to his isolated northern community. Exposing the northern community to potential problems protected the southern community. More serious, however, was the fact that the application of the Criminal Code in both cases disempowered the leaders of the community and placed the authority and responsibility for dealing with internal issues in the hands of non-Aboriginal people from the south.

I thought of these stories after reading Citizens Plus: Aboriginal Peoples and the Canadian State, by Canadian political scientist Alan Cairns. $^{2}$ In this book, he criticizes Canada's Royal Commission on Aboriginal Peoples ${ }^{3}$, which recommended that governments enter into negotiations with Aboriginal nations in order to increase the Aboriginal land base and to recognize lawmaking powers in their own communities. Cairns says that these agreements emphasize 'nation to nation' relationships, treaties and a third order of government for Aboriginal nations at the expense of fostering a 'common sense of belonging' through shared institutions with other Canadians. In the two communities described above, I wondered how it could be said that the application of the 'shared' Criminal Code fostered a 'sense of belonging' to Canada? From the point of view of the dominant, non-Aboriginal society, having

S Drummond, Incorporating the Familiar: Investigating Legal Sensibilities in Nunavik (Queen's University Press, 1997).

2 A Cairns, Citizens Plus: Aboriginal Peoples and the Canadian State (UBC Press, 2000) 51-2.

Royal Commission on Aboriginal Peoples, Report (Supply and Services Canada, 1996). ('Royal Commission, Report'). One of the complaints made by Cairns is that the majority of the seven Commissioners were Aboriginal. 
the same Criminal Code apply on and off reserve may have appeared to strengthen the connection to Canada. From the Aboriginal point of view, however, the 'sense of belonging' may not have been felt as a particularly positive experience and would likely have contributed to a further alienation from Canada.

\section{OVERVIEW OF SELF-DETERMINATION}

\section{A. THE NEED FOR SELF-DeterminAtion}

In Australia, Canada, New Zealand and the United States, Indigenous people have survived a very dark century when government policy was aimed at destroying their cultures and taking away their lands.

A low point was reached in Canada in 1969, when then Prime Minister Pierre Trudeau released the White Paper on Indian Policy. This initiative called for the legal termination of Indian status, dismantling of Indian reserves, repeal of the Indian Act, and amendment of the Constitution to eliminate federal jurisdiction over Indians. The White Paper referred to Indian claims to land as 'so general and undefined that it is not realistic to think of them as specific claims capable of [legal] remedy'. ${ }^{4}$ Trudeau apparently thought that he was doing nothing more than formally announcing what had already happened - the disappearance of the Indian. Much to his surprise, he was set back on his heels by the angry reaction of First Nations, and by court rulings recognizing Aboriginal title. His government had to do an about-face and institute a policy that addressed land claims and Aboriginal title.

Similar developments occurred in the other jurisdictions. In New Zealand, after years of hostility to Māori, the government enacted the Treaty of Waitangi Act 1975 that provided legislative recognition of the 1840 Treaty and establishment of the Waitangi Tribunal. The Tribunal, which incorporates both Māori and pakeha (non- Māori) personnel and procedures, has launched a series of hearings looking into land, resource

(University of Toronto Press, 2001) 268. 
and cultural rights of Māori. ${ }^{5}$ In Australia, a 1967 referendum approved changes to the Constitution that allowed the Commonwealth (federal) government to make laws with respect to Aboriginal people, and ensured that they would be taken into account for calculating state populations. In the 1970's the government began a policy favouring self-determination or self-management ${ }^{6}$, which has continued off and on since that time. The United States began the era of self-determination with President Richard Nixon's speech in 1970, which opened the way for the Indian SelfDetermination and Educational Assistance Act in 1975. This Act provided a mechanism for transferring responsibility for federal programs to tribes. ${ }^{7}$

These changes occurred partly because non-Indigenous governments realized that the era of assimilation had not worked. Indigenous people had survived massacres, European diseases, forced removal of their children and mass deportation out of their homelands. The 'Indian problem' had not disappeared: instead, the assimilation policy had exacerbated the problems and governments were left with the prospect of social and economic disaster in Indigenous communities. Indigenous people themselves impelled the change by joining the wave of consciousness that began in the Sixties. In 1966, in Australia, Vincent Lingiari led 200 fellow Aboriginal workers in the Wave Hill 'Walk-Off'. What began as a protest for the same pay as non-Indigenous employees turned into a seven year strike for the return of Aboriginal lands. ${ }^{8}$ In the United States the Trail of Broken Treaties was a caravan that departed from the West Coast in 1972. It traveled to various reservations, gaining support, before finishing in Washington DC, where Indians occupied

5 J Hayward and NR Wheen (eds), The Waitangi Tribunal (Bridget Williams Books, 2004)

6 C Gibson, 'Cartographies of the Colonial/Capitalist State: A Geopolitics of Indigenous Self-determination in Australia' (1999) 31 Antipode 45, 47.

See G Nettheim, GD Meyers and D Craig, Indigenous Peoples and Governance Structures: A Comparative Analysis of Land and Resource Management Rights (Aboriginal Studies Press, 2002) 32; The Harvard Project on American Indian Economic Development, The State of the Native Nations (Oxford University Press, 2008) 20-1 ('The Harvard Project'). For a review of economic development in Canada, see C Beal, "Aboriginal Economic Development" in G Bailey (ed), Indians in Contemporary Society (Smithsonian Institution, 2008) 231.

National Archives of Australia, Fact Sheet 24, at www.naa.gov.au/aboutus/publications/fact-sheets/fs224.aspx. 
offices of the Bureau of Indian Affairs. ${ }^{9}$ In Canada, a Native Peoples Caravan traveled across the country in 1974 and they were confronted by riot police on the steps of Parliament in Ottawa. ${ }^{10}$ In 1975, Whina Cooper led Māori in the Land March under the slogan 'not one more acre more of Māori Land'. The march began in the north part of the country and arrived in Wellington with 30,000 supporters. ${ }^{11}$

It is now clear that there are sound economic and social reasons for promoting self-determination. The Harvard Project on American Indian Economic Development has conducted a series of studies beginning in 1987 culminating in the publication of The State of the Native Nations. They show that self-determination and economic prosperity are inextricably linked. They reveal that poverty levels dropped on United States reservations exercising self-government powers, at a greater rate than poverty levels dropped in the general population. The studies also found that with greater self-government, leaders are more accountable to the members of the community and that their decisions are more likely 'in tune with the cultural values of the community'. ${ }^{12}$ Stephen Cornell, the cofounder of the project, is forthright in his view:

the U.S. record is clear: if central governments wish to perpetuate Indigenous poverty, its attendant ills and bitterness, and its high costs, the best way to do so is to undermine tribal sovereignty and self-determination. But if they want to overcome Indigenous poverty and all that goes with it, then they should support tribal sovereignty and self-determination, and they should invest in helping Indigenous peoples build the governing capacity to back up sovereign powers with effective governments of their own design. ${ }^{13}$

V Deloria, Behind the Trail of Broken Treaties: An Indian Declaration of Independence (Delacorte Press, 1974).

10 V Harper, Following the Red Path (Native Peoples' Press, 1979).

11 SC Bourassa and AL Strong, 'Restitution of Land to New Zealand Maori: The Role of Social Structure' (2002) 75 Pacific Affairs 227, 237.

12 The Harvard Project, above n 7, 70. For the website of the project, see www.ksg.harvard.edu/hpaied.

13 S Cornell, Indigenous Peoples, Poverty, Self-Determination in Australia, New Zealand, Canada the United States (Native Nations Institute for Leadership, 2006) 28. 
The social basis for a self-determination policy is also sound. Michael Chandler and his colleagues have conducted a series of interesting studies, trying to understand why some suicide rates on Indian reserves in British Columbia, Canada, were 800 times the national average, and on others, suicide was practically unknown. Their conclusions are remarkable. They find that suicide rates are lower in communities that have retained their own language. In addition, Bands have higher rates of youth suicide when they lack measures of self-government over areas such as health, education, child protection, policing, access to traditional lands, and the construction of facilities for preserving cultural artifacts and traditions. ${ }^{14}$

Claire Charters, in her chapter, discusses the growing recognition of the self-determination rights of Indigenous peoples at the international level. The most recent is the United Nations Declaration on the Rights of Indigenous People, Article 3, which recognizes the right to selfdetermination: 'Indigenous peoples have the right to self-determination. By virtue of that right they freely determine their political status and freely pursue their economic, social and cultural development'. ${ }^{15}$

\section{B. What is SELF-Determination?}

A wide variety of terms are used to describe the general policy approach described in this chapter. A Māori commentator from Aotearoa/New Zealand says:

Maori aspiration for greater control over their own destinies and resources is variously described as a search for sovereignty, autonomy, independence, self-governance, self-determination, tino rangatiratanga, and mana motuhake. There are important distinctions between those terms, though they all capture an underlying commitment to the advancement of Maori people as Maori, and the

D Hallett, MJ Chandler and CE Lalonde, 'Aboriginal Language Knowledge and Youth Suicide' (2007) 22 Cognitive Development 292, 292. The first study on cultural continuity was MJ Chandler and CE Lalonde, 'Cultural Continuity as a Hedge Against Suicide in Canada's First Nations’ (1998) 35 Transcultural Psychiatry 191.

15 United Nations Declaration on the Rights of Indigenous Peoples, GA Res A/RES/61/295, UNGA, 61st Sess (Sept 13, 2007). 
protection of the environment for future generations. And all reject any notion of an assimilated future. ${ }^{16}$

Agreement on terminology is rendered more difficult because Indigenous and non-Indigenous parties may formulate the problem in entirely different ways. Non-Indigenous governments and courts tend to analyze the issue in relation to relative powers and jurisdictions. What laws will Indigenous people be able to enact? Will Indigenous laws be subservient to federal laws? What institutions will be established to implement policies? Indigenous parties, on the other hand, tend to view the issues in terms of on-going resistance to the encroachment of non-Indigenous social, economic and political structures. ${ }^{17}$ Their approach to selfgovernment may be better understood as a 'bundle of dynamic legal relationships, political aspirations and affirmations of cultural continuity'. 18

The difference in these approaches may be illustrated by comparing the Canadian government's negotiation policy on selfgovernment, with the approach of Canadian Aboriginal academic John Borrows. The federal government policy recognizes that there is an inherent right of self- government and sets out what areas of jurisdiction are negotiable, whom the government will negotiate with, and how negotiated agreements are to be ratified. A major objective is to harmonize laws: 'it is in the interest of both Aboriginal and non-Aboriginal governments to develop co-operative arrangements that will ensure the harmonious relationship of laws which is indispensable to the proper functioning of the federation'. ${ }^{19}$ Borrows, on the other hand, in 'A Genealogy of Law: Inherent Sovereignty and First Nations Selfgovernment', recounts his family history going back to the great Shawnee

16 M Durie, Te Mana, Te Kawanatanga: The Politics of Maori Self-determination (Oxford University Press, 1998) 218.

17 See F Barth, 'Preface, 1998' in F Barth (ed), Ethnic Groups and Boundaries: The Social Organization of Culture Difference (Waveland Press, 1969, 1998) 7 ('... in analysing Indigenous people's political activism, we discussed the shift to seeing such groups as engaged in a social struggle for meaningful change, not the revitalization of an unchanging heritage of aboriginal cultural traits'.).

18 S Imai, Aboriginal Law Handbook (2nd edn, Carswell, 1999) 116. ('Imai, Handbook')

19 See 'The Government of Canada's Approach to Implementation of the Inherent Right and the Negotiation of Aboriginal Self-Government' ('federal selfgovernment policy'), at www.ainc-inac.gc.ca/pr/pub/sg/plcy_e.html. 
leader, Tecumseh, who fought with the British against the Americans during the War of 1812. Borrows points out that Tecumseh fought as an ally to the British, not as a subject, with the objective of protecting Indian lands. Borrows talks about a great-great-grandmother who was a medicine woman and who kept alive the traditions of her people. He talks about other ancestors who converted to Christianity and signed treaties, and relates this history to the present-day actions of the Chippewas of the Nawash Band Council. Through all this, he shows how the Indigenous people asserted their autonomy in the face of huge pressures. Of his methodology, Borrows says

the term 'self-government' does not require a legal or technical definition because I do not refer to selfgovernment as an abstract, futuristic institution. I identify self-government with particular events in which our people have exercised specific instances of control in their internal and external societal relationships. ${ }^{20}$

Of course, the federal policy and the reflections by Borrows are not comparable because they were drafted for different purposes. But that is precisely the point. The parties may come to the negotiating table for very different purposes, making communication a challenge.

The difference between the parties does not lie only in the different expectations of the process. The parties may also conceptualize 'difference' itself in different ways. Non- Indigenous governments generally see this 'difference' as a set of static practices, some of which can continue today and others that are of no relevance in the contemporary world. Much of the current judicial thinking on 'culture' and 'tradition' is also static and judgmental. It is based on the view that cultural practices and beliefs can be taken apart and catalogued into 'integral' and 'incidental' value to the social group. For example, in the Supreme Court of Canada decision, $R v$ Van der Peet, Lamer CJ thought that it was reasonable to ask Aboriginal groups to demonstrate that a pre-contact 'practice, tradition or custom was one of the things which made the culture of the society distinctive - that it was one of the things that truly made the

20 J Borrows, 'A Genealogy of Law: Inherent Sovereignty and First Nations Selfgovernment' (1992) 30 Osgoode Hall Law Journal 291, 294. 
society what it was'. ${ }^{21}$ He felt that it would be possible to do this while excluding those practices that 'are true of every human society (e.g., eating to survive)'. ${ }^{22}$ This approach has been criticized by John Borrows for freezing Aboriginal societies in the past:

Chief Justice Antonio Lamer has now told us what Aboriginal means. Aboriginal is retrospective. It is about what was, 'once upon a time', central to the survival of a community, not necessarily about what is central, significant and distinctive to the survival of these communities today. His test invites stories about the past. ${ }^{23}$

The static view of culture arose at a time when societies were viewed hierarchically with some cultures being more advanced than others - some so low on the scale of human development that they deserved to be enslaved or exterminated. Modern anthropology no longer subscribes to those views. Culture is not a static group of attributes that can be placed in a hierarchical order, but rather a dynamic, ever changing complex of relationships. Commenting on the Van der Peet decision, anthropologist Michael Asch says: 'culture is a system and a process rather than merely items and arrangements. It is inappropriate to attempt to ferret out whether a practice, custom or tradition is "distinctive". ${ }^{24}$

This dynamic experience of culture may be why many Indigenous people are attracted to the concept of 'self-determination'. It refers to the right of a people to decide how it wants to relate to a majoritarian population. As

$21 \quad$ [1996] 2 SCR 507, para 55.

22 Ibid, para 56: 'The court cannot look at those aspects of the aboriginal society that are true of every human society (eg, eating to survive), nor can it look at those aspects of the aboriginal society that are only incidental or occasional to that society; the court must look instead to the defining and central attributes of the aboriginal society in question'. Subsequent cases, including Sappier $v$ The Queen [2006] 2 SCR 686, have backtracked a little from this position.

23 J Borrows, 'Frozen Rights in Canada: Constitutional Interpretation and the Trickster' 22 American Indian Law Review 37, 43. A similar observation for the Inuit is made by Drummond, above n 1, 42 ('Fixing Inuit culture at the period of the ethnographer's fieldwork ignores the unceasing dynamism of groups that are constantly forming and reforming in the grip of the contingencies of time. Such ahistorical depictions prevent the Inuit from sharing the present with us'.). M Asch 'The Judicial Conceptualization of Culture after Delgamuukw and Van der Peet' (2000) Review of Constitutional Studies 119, 129. 
understood in international law, it does not say what form the association will take. Technically both the option of full sovereignty and the option of complete assimilation are open. 'Self-determination' refers to a choice, not a particular institutional relationship. It is dynamic and not fixed on particular arrangements. In the next section, I will discuss four possible outcomes from the exercise of self-determination: sovereignty and selfgovernment; self- administration and self-management; co-management and joint management; and participation in public government.

\section{THE EXERCISE OF SELF-DETERMINATION}

Because self-determination is a choice, it can be exercised in different ways. The 'sovereignty and self-government' option leads to more autonomy for the Indigenous community to control its own social, economic and political development. The 'self-management and selfadministration' option leads to greater control of local affairs and the delivery of services within a larger settler government legislative framework. The 'co-management and joint management' model institutionalizes Indigenous participation in the management of lands and resources. The 'participation in public government' option provides a means to influence the policies of the settler governments through Indigenous-specific institutions. Within each category, there are a number of variations. These options are not mutually exclusive and in some jurisdictions, all four forms co-exist.

\section{A. SOVEREIGNTY AND SELF-GOVERNMENT}

In no jurisdiction does use of the term 'sovereignty' connote the existence of a separate international state. Rather, the sovereignty and selfgovernment models are characterized by the recognition of an inherent Indigenous authority to make laws over a defined territory. These Indigenous governments do not rely on delegated authority from settler government legislation. This does not mean that domestic courts recognize that Indigenous nations have plenary authority. In both the United States and Canada, courts and legislation have imposed limitations on the autonomy of these governments. 


\section{THE UNITED STATES}

Indian tribes in the United States have the most explicit recognition of their autonomy. Since 1821, the Supreme Court of the United States has described the tribes as 'domestic dependent nations', 25 and recognized their prior possessory rights to their territory. As one notable case explained: '[t]he Indian nations had always been considered as distinct independent political communities, retaining their original natural rights, as the undisputed possessors of the soil, from time immemorial'. ${ }^{26}$ This means that the tribes derive their authority independently of the Constitution of the United States, and only Acts of Congress can limit their authority.

The sovereignty that the Indian tribes retain is of a unique and limited character. It exists only at the sufferance of Congress and is subject to complete defeasance. But until Congress acts, the tribes retain their existing sovereign powers. In sum, Indian tribes still possess those aspects of sovereignty not withdrawn by treaty or statute, or by implication as a necessary result of their dependent status. ${ }^{27}$

The most significant Congressional incursion has been the Major Crimes Act, ${ }^{28}$ of 1885, which gives the federal courts jurisdiction over more than a dozen offences such as murder, kidnapping and rape. Other statutes that limit tribal authority include the Indian Civil Rights Act, ${ }^{29}$ which gives individual Indians recourse against their tribal governments for violation of their civil liberties; and Public Law 280, ${ }^{30}$ which transferred some federal authority to about sixteen states in 1953. Nonetheless, the 'doctrine of retained sovereignty' has survived. Therefore, in the absence of Congressional legislation, the tribes can enact their own laws and administer their own justice system. Today, tribal codes cover a wide

Cherokee Nation v Georgia 30 US (5 Pet) 1, 17-20 (1821).

Worcester v Georgia 31 US (6 Pet) 515, 559 (1832).

US $v$ Wheeler, 435 US 313, 322-23 (1978).

Major Crimes Act, 18 USC s 1153.

Indian Civil Rights Act 1968, 25 USC ss 1301. This statute is necessary because the sovereign status of tribal governments means that they do not derive their powers from the American constitution. Consequently, the Bill of Rights contained in the American constitution does not apply to tribal governments.

Pub L 83-280, 67 Stat 588 (1953). 
range of subject matter including criminal offences not covered by the Major Crimes Act, commercial relations, land use, marriage and child welfare. ${ }^{31}$ There are about 275 tribal courts in the United States and many tribes have courts of appeal. ${ }^{32}$ The extent to which tribal jurisdiction extends to non-Indians has been litigated several times in the Unites States Supreme Court. The current law, in a nutshell, is that in most cases the tribal jurisdictions do not apply to non-Indians. ${ }^{33}$

FROM THE MID SEVENTIES ONWARD, CONGRESS PASSED A NUMBER OF LAWS THAT ENCOURAGED GREATER EXERCISE OF TRIBAL POWERS. THE MOST SIGNIFICANT, IN TERMS OF THE RECOGNITION OF TRIBAL AUTHORITY, WAS THE INDIAN CHILD WELFARE ACT OF 1978. THIS ACT EXPLICITLY RECOGNIZES TRIBAL JURISDICTION OVER INDIAN CHILDREN RESIDING ON RESERVATIONS, AS WELL AS PROVIDING FOR THE TRANSFER OF JURISDICTION OVER INDIAN CHILDREN LIVING OFF THE RESERVATION FROM STATE TO TRIBAL COURTS. IN CASES WHERE THERE IS NO TRANSFER, THE STATUTE GIVES THE TRIBE THE RIGHT TO INTERVENE IN THE PROCEEDINGS. ${ }^{34}$

\section{CANADA}

Prior to 1982, the Canadian government and courts did not acknowledge that Indigenous peoples have inherent government powers. The only authority granted to Indians was through the Indian Act, which established elected Band Councils which could only enact by-laws on local matters. The other two Indigenous peoples in Canada, the Inuit and the Métis,

$31 \quad$ For a description of tribal jurisdiction see DH Getches, CF Wilkinson and RA Williams Jr, Cases and Materials on federal Indian Law (5th edn, West Publishing, 2005) 456-54; and The Harvard Project, above n 7, 37-51.

32 These courts generally follow American adjudication processes but many are introducing traditional peacekeeper functions. See National Tribal Resource Centre, www.tribalresourcecenter.org/tribalcourts/history.asp; and the chapter in this reader by Christine Zuni Cruz.

33 The leading case limiting tribal criminal jurisdiction over non-Indians is Oliphant $v$ Suquamish Indian Tribe, 435 US 191 (1978). For a recent case limiting civil jurisdiction over non-Indians, see Plains Commerce Bank v Long Family Land \& Cattle Co, 554 US __ (2008).

$34 \quad$ Indian Child Welfare Act, 1978, 25 USCA, s 1911. 
faired even worse as there was almost no formal recognition of their existence as collectivities.

In 1982, Canada amended its Constitution. Among other things, it added a provision recognizing rights of the Aboriginal peoples of Canada:

s.35(1) The existing aboriginal and treaty rights of the aboriginal peoples of Canada are hereby recognized and affirmed.

(2) In this Act, 'aboriginal peoples of Canada' includes the Indian, Inuit and Métis peoples of Canada. ${ }^{35}$

Although no rights were specifically mentioned, the Royal Commission on Aboriginal Peoples, in its 1996 report, reasoned that a right of selfgovernment was already included in section 35(1). ${ }^{36}$ While the Supreme Court of Canada has yet to decide whether this is correct, it has held that assertion of a general right of self-government over reserve land is too broad; instead, self-government rights need to be proven on a specific, case-by-case basis. Nonetheless, the Court has decided that, in cases involving Aboriginal title and treaty rights to fish, Aboriginal peoples have some decision-making authority. ${ }^{3}$

In the meantime, the federal government has committed itself to recognizing the existence of the inherent right to self-government. Based on the federal self-government policy, negotiations have continued on land claims and self- government. Over a dozen significant agreements have been signed since the mid seventies, as well as scores of minor settlements for land disputes. The land portions of these agreements range from

35 Constitution Act 1982, being Sch B to the Canada Act 1982 (UK) s 35.

36 See Royal Commission, Report, above n 3, Vol 2 Pt 2, 245-65.

Generally, see K McNeil, 'Judicial Approaches to Self-Government since Calder: Searching for Doctrinal Coherence' in H Foster, H Raven and J Webber (eds), Let Right Be Done: Aboriginal Title, the Calder Case, and the Future of Indigenous Rights (UBC Press, 2007) 129. In $R$ v Pamajewon [1996] 2 SCR 821 the Court held that holding a bingo without a provincial license did not fall under a right of self-government, and left open the question of whether such a right could exist. Other cases have suggested that First Nations have authority over Aboriginal title land (Delgamuukw v British Columbia [1997] 3 SCR 1010), and treaty rights (Marshall $v$ Canada [1999] 3 SCR 533), without specifically finding that a right of self-government existed. 
136,000 square miles of land for the Inuit of the Eastern Arctic to 2.7 square miles for Tsawwassen in British Columbia. ${ }^{38}$

While all of these agreements contain a self-government component, the Nisga'a Agreement of British Columbia is among those that go the furthest, by giving the self- government powers constitutional status. Because the rights contained in the Nisga'a Agreement are section 35 (1) 'treaty rights', ordinary legislation cannot derogate from them. They thus enjoy much greater protection than self-government rights in the United States, where Congress has plenary power to derogate from tribal authorities. However, the extent of Nisga'a jurisdiction is considerably more restricted than that of the Navajo in the United States, or even than that envisaged by the Royal Commission on Aboriginal Peoples. Nisga'a authority is paramount over some internal matters, including Nisga'a government and constitution, ${ }^{39}$ Nisga'a citizenship, ${ }^{40}$ culture and language ${ }^{41}$ Nisga'a property, ${ }^{42}$ use of Nisga'a lands,${ }^{43}$ child and family services, ${ }^{44}$ education, ${ }^{45}$ and cultural property. ${ }^{46}$ In other areas, the provincial or federal government laws are either paramount (eg, health services and intoxicants), or are exclusive (eg, criminal law). As for adjudication of disputes, the Agreement provides for the creation of a Nisga'a court if provincial approval is obtained, ${ }^{47}$ but any appeals must be taken to Supreme Court of British Columbia. ${ }^{48}$ Finally, the form of government does not look radically different from Indian Act's Band Councils.

\footnotetext{
38 For a more detailed description of some of these agreements, see S Imai, 'Aboriginal Land Claims' in Handbook of North American Indians, vol 2 (Smithsonian Institution, 2008) 177-84. See also the Department of Indian and Northern Affairs (www.ainc-inac.gc.ca) and the British Columbia Treaty Commission (www.bctreaty.net).

$41 \quad$ Ibid, $\mathrm{s} 41$.

$42 \quad$ Ibid, $\mathrm{s} 44$.

$43 \quad$ Ibid, $\mathrm{s} 47$

$44 \quad$ Ibid, s 89

$45 \quad$ Ibid, ss 100, 103. $46 \quad$ Ibid, s 115.

$47 \quad$ Ibid, s 36. $48 \quad$ Ibid, ch 12, s 45.
} 


\section{Australia AND New ZEALAND}

The courts in Australia and New Zealand have traditionally not recognized any sovereignty for Indigenous people. In fact, in 1971 an Australian case, Milirrpum v Nabalco Pty. Ltd. $^{49}$ decided that, as a matter of law, Australia was terra nullius when the first settlers arrived. That is, the land was empty. Far from recognizing any rights to land or self-government, the Court found that the Aborigines did not even exist as people with rights. It was not until 1992, that the High Court in Mabo reversed this decision and recognized the existence of native title in Australia. ${ }^{50}$ In New Zealand, the existence of Māori sovereignty turns on the meaning of the 1840 Treaty of Waitangi. The Māori version of the treaty states that the Māori retained tino rangatiratanga over their taonga, which roughly translates to sovereignty over their treasures. The English version of the Treaty states that Māori ceded all of their sovereignty to the British Crown. While there was a period when the Treaty was completely ignored, courts and government have now begun to recognize some Māori interests in relation to land and resources. ${ }^{51}$ However, in neither country have courts recognized sovereignty in the way that courts in the United States have. As a consequence of the hostile judicial environment, in neither country have land settlements with Indigenous people resulted in the combination of land and jurisdiction that has characterized policy toward American tribes and recent Canadian land claims settlements.

Nonetheless, sovereignty is part of the political vocabulary of Australian Indigenous people and Māori. In Australia, in the late 1980's during the debates on negotiating a modern treaty, some Aboriginal leaders suggested that Aboriginal Australians should seek full independence as a country. ${ }^{52}$ This idea does not appear to have gained much traction, but there is interest in looking for a new arrangement within Australia. Will Sanders argues that Indigenous people in Australia have jurisdiction to make their own laws and that they represent 'a

\footnotetext{
$49 \quad$ Milirrpum $v$ Nabalco Pty Ltd. (1971) 17 FLR 141. See also Coe $v$ Commonwealth (1979) 53 ALJR 403.

$50 \quad$ Mabo v State of Queensland (No 2) (1992) 107 ALR 1 (HC). See the chapter by Kent McNeil for a fuller discussion.

$51 \quad$ See Bourassa and Strong, above $\mathrm{n} 11$.

52 N Pearson, 'Reconciliation: To Be or Not To Be - A Separate Aboriginal Nationhood or Aboriginal Self-determination and Self-government Within the Australian Nation?' [1993] Aboriginal Law Bulletin 12.
} 
repressed third order within Australian government, alongside the State and Commonwealth orders'. ${ }^{53}$ Lisa Behrendt suggests that the aspiration of the treaty would be for 'internal self-determination' within the Australian state:

[t]he rights enmeshed in the concept of 'self-determination' include, I would argue, everything from the right not to be discriminated against, to the rights to enjoy language, culture and heritage, our rights to land, seas, waters and natural resources, the right to be educated and to work, the right to be economically self sufficient, the right to be involved in decision-making processes that impact upon our lives and the right to govern and manage our own affairs and our communities. 54

Similarly, Andrea Tunks from Aotearoa/New Zealand states flatly, '[s]ecession is not at the forefront of Māori aspirations'. 55 She sees the Treaty of Waitangi as recognizing the existence of a parallel Māori lawmaking authority:

Minimally, it would enable hapu [tribes] and iwi [tribal confederations] to exercise law-making power in respect of their territories, resources and their own members. It may also include an ability for pan-tribal structures to gather separate tribal nations into one decision-making entity so that the relationship with Crown kawantanga [governmental authority] and non-Māori can be continually negotiated. $^{56}$

53 W Sanders, 'Towards an Indigenous Order of Australian Government: Rethinking Self-determination as Indigenous Affairs Policy', Discussion Paper No 230/2002 (Centre for Aboriginal Economic Policy Research, University of New South Wales, 2002).

54 L Behrendt, 'Unfinished Journey - Indigenous Self Determination' (2002) 58 Arena Magazine 24, 27.

55 A Tunks, 'Pushing the Sovereign Boundaries in Aotearoa' [1999] Indigenous Law Bulletin 69, text at fn 34.

$56 \quad$ Ibid. 


\section{B. SELF-ADMINISTRATION AND SELF-MANAGEMENT}

In these arrangements the Indigenous community does not exercise inherent authority. They derive their powers from, and are limited by, settler government legislation and policies. The most advanced variation of this model includes a land base. These variations usually include powers for Indigenous institutions to make by-laws over local matters. Where there is no land base, there can be a transfer of a government program and attendant funding to an Indigenous organization. These selfadministration and self-management initiatives have brought significant benefits by way of control over funding and the potential for more appropriate service delivery. However, they have been criticized for being a poor replacement for true self-government or sovereignty. ${ }^{57}$

\section{SELF-ADMINISTRATION ON A LAND BASE}

The Indian Act regulates most Canadian Indians. ${ }^{58}$ This statute has the dual purpose of shielding Indians from the settlers, but also promoting eventual assimilation. It set aside reserves for Indian communities and shields the land from being sold off piecemeal, by requiring that communities consent to the 'surrender' of the land. ${ }^{59}$ The Act sets out rules for a wide variety of matters including membership, education, land use, wills and taxation. The Indian Act also gives the government almost complete control over the day-to-day functioning of the elected Band Council. For example, the government has imposed western style elections on Bands, thereby displacing traditional governance structures. Although the Act gives Band Councils authority to make by-laws, the subject matter is limited to local issues, such as consumption of alcohol and residence on the reserve. Even with this limited jurisdiction, the Minister of Indian

\footnotetext{
$57 \quad$ See eg, Cornell, above n 13, 10-11.

$58 \quad$ Indian Act, 1876, RSC 1985, c I-5.

59 The land set aside for Indian reserves in a fifty- year period beginning in the mid 1800's was minuscule compared to American standards. All the reserves in Canada put together would have been less than one half of the size of the Navajo reserve alone. See Royal Commission, Report, above n 3, Vol 2, Pt. 1, 422-23. Modern land claims agreements beginning in the mid-seventies, described above, have increased the total amount of land under the jurisdiction of Aboriginal people in Canada.
} 
Affairs can disallow any Band Council by-law. ${ }^{60}$ At the present time, only a small minority of First Nations have succeeded in negotiating the self government arrangements discussed earlier in this chapter that have freed them from the Indian Act.

Canada's Métis are recognized as having self-administration powers only in the Province of Alberta where they have a similar type of arrangement to the Indian Act. The Métis Settlements Act established eight communities with governing bodies that can make local decisions. ${ }^{61}$

The Indian Bands and the Métis Settlement Councils receive government funding to administer their reserves and settlements. They are also eligible to receive funds to deliver social services and economic development projects. In this, they are similar to American tribes who administer quite a range of federal programs through the Indian Selfdetermination and Education Assistance Act. ${ }^{62}$

In Australia, the Corporations (Aboriginal and Torres Strait Islander) Act $2006^{63}$ permits Aboriginal groups to create their own associations related to business, to land councils and town councils. Over three thousand entities have been created under this Act. ${ }^{64}$ The powers of these associations vary, depending on what State or federal statute provided them with jurisdiction, but in all cases, the authority to make laws is more limited than the authority delegated to Canadian Indian Bands. ${ }^{65}$ For example, in the Northern Territory, Land Councils under Aboriginal Land Rights (Northern Territory) Act 1976 are empowered to consult with landowners and negotiate land issues. The only regulatory powers they can exercise however, are, with the permission of the appropriate Minister, functions set out in the law of the Territorial government relating to (a) the protection of sacred sites; (b) access to Aboriginal land; and (c) schemes for the management of wildlife on

60 For a general description, see Imai, Handbook, above n 18, chs 8-10.

61 C Bell, Alberta's Métis Settlement Legislation: An Overview of Ownership and Management of Settlement Lands (Canadian Plains Research Center, University of Regina, 1994).

62 Indian Self-determination and Education Assistance Act, Pub L No 93-638, 88 Stat 203 (1975).

63 Corporations (Aboriginal and Torres Strait Islander) Act 2006 (Cth); formerly Aboriginal Councils and Associations Act 1976 (Cth).

64 T Anthony, 'Aboriginal Self-determination after ATSIC: Reappropriation of the "Original Position"” (2005) 14 Polemic 4, 6.

65 See Nettheim, et al, above n 7, 237-317. 
Aboriginal land. ${ }^{66}$ Indigenous communities in the Northern Territory can also carry out some local administrative functions if they are approved under the Local Government Act. Under this statute, a Council has power to make by-laws over a very limited number of local issues including alcohol consumption, the destruction of animals and issuing of licenses. ${ }^{67}$

\section{SELF-ADMINISTRATION OFF A LAND BASE}

Traditionally non-Indigenous people administered social services and economic development project in Indigenous communities. There are many horror stories from past years, ranging from the indiscriminate 'scooping' of Indigenous children by over zealous child welfare agencies to the imposition of economic 'development' schemes that only benefited non-Indigenous developers. The decisions taken in the 1970's and 1980's to transfer the administration of these programs to Indigenous people themselves would appear to be a good thing. There are critiques, however, that programs designed by non- Indigenous people, will not be necessarily be appropriate or even feasible, in Indigenous communities. ${ }^{6}$

An example that shows both the strengths and weaknesses of the self-administration model is the Aboriginal and Torres Straight Island Commission (ATSIC) of Australia. This organization was established in 1990 in response to the demand for 'self-determination'. It was composed of an eighteen member Board of Commissioners who were elected from 35 Aboriginal Regional Councils. It was established to provide advice to the government on issues affecting Aboriginal people and to assist Aboriginal communities. ${ }^{69}$ At its height, it provided vigorous advocacy and brought Australian issues to international fora. On the domestic front, ATSIC was involved in the delivery of a variety of funding programs in the arts, Indigenous rights, housing, economic development and legal services. ${ }^{70}$ Although ATSIC played an impressive role in the Australian political landscape, there were problems with the design. Some critics said that ATSIC was too focused on addressing disadvantage of Aboriginal individuals, rather than pursuing self-government goals such as land

66 Aboriginal Land Rights (Northern Territory) Act 1976 (Cth) s 23(2).

$67 \quad$ Local Government Act 1994 (NT) ss 182-201.

68 Imai, Handbook, above n 18, 182-83.

$69 \quad$ Aboriginal and Torres Strait Islander Commission Act 1989 (Cth) s 7.

70 The ATSIC web site is now closed, but some pages are archived at: pandora.nla.gov.au/pan/41033/20060106-0000/ATSIC/default.html. 
claims. Other critics noted that federal government control over the organization and its activities was very tight. The employees were not hired directly by ATSIC, but rather through the federal bureaucracy; for the first decade, the Chair was appointed by the government; and almost all of the programs were delivered under guidelines provided in Australian legislation. Consequently, in spite of the fact that the leadership of ATSIC was Aboriginal, the organization itself was criticized for being too 'white'. In addition, there were internal challenges. The elected Board of Commissioners were said to be too involved in decision-making on funding, leading to charges of favouritism. As a consequence, in 2003, the service delivery functions were transferred to the Aboriginal and Torres Straight Islander Services. The political vulnerability of an Indigenous government structure based on delegated authority was illustrated when, in 2005, a conservative Australian government shut down the organization and transferred the service delivery options to other institutions and government departments. ${ }^{71}$

In spite of these critiques, in urban settings, self- administration may provide a valuable vehicle for Indigenous people. The urban populations are significant. In New Zealand, over 85 per cent of the Māori live in urban centres; ${ }^{72}$ in the United States about 67 per cent live off reservations and half in urban centres ${ }^{73}$; in Australia, about 30 per cent of Aborigines live in major urban areas ${ }^{74}$ and almost half live in urban areas in Canada. ${ }^{75}$ People living in non-Indigenous areas do not have an exclusive land base, and the communities are often fragmented, as individuals have different degrees of identification with their indigeneity. ${ }^{76}$ Although there are calls for 'self-determination for urban Indians', ${ }^{77}$ such self-determination must result in arrangements that are different from

71 See Nettheim et al, above n 7, 379 -81. See general critiques by Anthony, above n 64.

72 Durie, above n 16, 55.

73 Harvard Project, above n 7, 321-66.

74 From Human Rights and Equal Opportunity Commission, Australia, drawing on 2001 statistics: www.hreoc.gov.au/Social_Justice/statistics/index.html\#fn28, drawn from ABS stats.

75 Statistics Canada: www12.statcan.ca/english/census01/Products/Analytic/companion/abor/canada. cfm\#6.

76 See Durie, above n 16, 95 (discussing alienation of urban Māori from traditional iwi).

$77 \quad$ Harvard Project, above n 7, 359. 
communities with a land base. Rather than beginning with an identifiable community and a geographical location, the project might build up from the services that are used by Indigenous people such as education, community centres, housing, employment training or child welfare. The institutions providing the services could facilitate participation by Indigenous people through reserving seats on the board of directors or establishing liaison or advisory committees. In addition, where numbers warrant, Indigenous people themselves could be funded to run some services. In the city of Toronto, Canada, where there is an Indigenous population of perhaps 60,000 , there are many Indigenous-specific services run by Indigenous peoples, including two community centres, a cooperative housing project, an elementary school, a legal aid clinic, a library, a health clinic, a men's residence, a senior's residence and a child welfare agency. ${ }^{78}$ In the best of these models, the Aboriginal people not only deliver the service, they also play important roles in the design and decision-making.

It may be possible to go a step further by co-ordinating all of these services under an umbrella organization. This is the form of selfgovernment suggested by Canada's Royal Commission on Aboriginal Peoples, called 'communities of interest'. ${ }^{79}$ In this model, Indigenous people would centralize the delivery of services and provide a structure for advocating for their members. It is similar to the Australian ATSIC model: an elected Indigenous body involved in service delivery and advocacy. To my knowledge, outside of Australia, no group has been able to implement this model for urban self-government.

\section{Co-MAnAgEment AND Joint MANAGEMEnT}

The areas of land that are reserved or set aside for the exclusive use of Indigenous people is often not large enough to provide the support necessary for traditional ceremonial and sustenance activities, let alone for modern day economic pursuits that will provide an economic base for the communities. Indigenous peoples need access to, and control over, the land and resources, not only in their small exclusive use areas, but also in

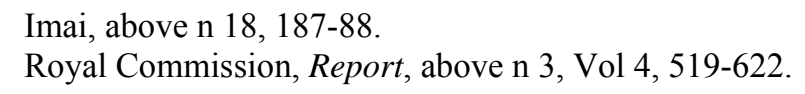


the larger land and resource base that they have traditionally accessed to survive.

It is difficult to measure whether or not there has been 'progress' on the lands issue over the years. Certainly, in Canada, Australia and New Zealand, the situation has improved, in that governments in all three jurisdictions have said that they are committed to addressing issues of land and resources. Kent McNeil's chapter on land rights in this reader shows that there have been advances in recognizing title for Indigenous groups, including the recognition in both international law and domestic law, that governments must consult with Indigenous peoples before taking away Indigenous access to lands or resources. On the other hand, this is the area where Indigenous people encounter the greatest pressure to assimilate. Mining, gas and oil, forestry, agriculture, hydro-electric power generation, settlement: they can all combine to create a rationale for pursuing a 'public good' that results in the transfer of the ownership and management of lands from the Indigenous inhabitants to the settler governments. Physical confrontations over land continue in Canada, the United States, Australia and New Zealand, resulting in road blockades and land occupations. ${ }^{80}$ Gordon Christie is critical of the imposition of a dominant vocabulary on the issues:

While pre-existing Aboriginal interests may be transformed into proprietary, or quasi-proprietary rights, Aboriginal sovereignty is removed from the scene at the point of the assertion of Crown sovereignty (replaced with, at most, the notion of 'self-government' - another construct within domestic Canadian law). The Crown is charged exclusively with the task of deciding how land is to be thought of, and how this translates into how land is used. Vital Aboriginal interest, those which exist today as 'unsettled' claims, are to be replaced with 'rights' and 'title', constructs essentially unrelated to these vital interests, and distanced from Aboriginal sovereignty. These constructs are grounded in non-Aboriginal visions - state visions - of interests Aboriginal nations might have in their lands, nonby the police, see Ontario Government, Report of the Ipperwash Inquiry (Publications Ontario, 2007). 
Aboriginal visions which are directed toward
economic/exploitative ends.

The question then, is not only a question of law. In Canada, at least, some First Nations were better off not having any recognized rights in law, but having control and use of their resources in fact. The coming of legal recognition has been accompanied by an invasion of their lands and an expropriation of their resources.

The obligation to 'consult' with Indigenous communities is certainly an improvement over the past, when no consultation was necessary. However, settler governments are loath to acknowledge that Indigenous 'consent' is required. This means that no matter how elaborate the consultation process, courts and governments do not recognize the community's right to say 'no'. Recently in Ontario, Canada, the Kitchenuhmaykoosib Inninuwug were involved in a dispute in the bush hundreds of miles from any road, in an area accessible only by plane and skidoo. The First Nation objected to exploration activity on territory over which it still retained rights to hunt and fish. A court ordered the First Nation to participate in a 'consultation' with the company, Platinex. Throughout the consultation, the First Nation insisted that it intended to follow its own protocols before deciding whether to permit further exploration. After some months had passed, the judge decided that the First Nation's right to be consulted had been fulfilled. When the First Nation continued to block exploration activity, the judge found that the Chief and the majority of the members of the elected council were guilty of contempt of court and he sentenced them to six months in jail. ${ }^{82}$ It was the longest sentence that people could remember for a contempt of court arising from protest actions. ${ }^{83}$ As for precedents, no examples come to mind of an entire mayor and council of a non-Aboriginal municipality

81 G Christie, 'A Colonial Reading of Recent Jurisprudence: Sparrow, Delgamuukw and Haida Nation' (2005) 3 Windsor Yearbook of Access to Justice 17, 46.

82 Platinex Inc v Kitchenuhmaykoosib Inninuwug First Nation [2008] 2 CNLR 201 (Ont Sup Ct).

83 See Frontenac Ventures Corp v Ardoch Algonquin First Nation [2008] OJ 2651 (Ont CA) para 63. In this case, the trial judge had imposed a sentence of six months and a fine of $\mathrm{C} \$ 25,000$ to former Chief for blocking a uranium mine on disputed land. The Ontario Court of Appeal found the sentence much too harsh and reduced it to a $\mathrm{C} \$ 1000$ fine. 
being jailed over a dispute over land use. To exacerbate matters, Platinex was not an innocent, well-meaning resource company. Although the company had received a letter from the First Nation objecting to the exploration activity, in their public listing they said that the Band had verbally consented to the exploration. ${ }^{84}$ When the Band physically prevented the exploration activity, Platinex sued for over C\$10 billion. That was about C\$10 million for every man, woman and child on this isolated reserve.

A softer way for governments to access Indigenous lands is through co-management regimes. In the typical case, a commission or board is established with Indigenous and government appointees. The idea is that this type of structure will facilitate a collaborative relationship that embeds Indigenous participation. Canada uses co-management boards extensively and they are an important feature of all land claims agreements. ${ }^{85}$ The jurisdiction and composition of each board depends on the land claims agreement. An example is found in the Nunavut Land Claims Agreement. ${ }^{86}$ A number of wildlife management, resource management and environmental boards are established to provide Inuit with a formal role in making recommendations to government decisionmakers. These include the Nunavut Planning Commission, the Nunavut Water Board, the Nunavut Wildlife Management Board and the Surface Rights Tribunal. The Boards are generally composed of the same number of representatives from the Tunngavik Federation of Nunavut as from the federal and territorial governments. Since Inuit will dominate the territorial government, the majority of the members of a Board may be Inuit people. For the most part, the decisions of the co-management bodies remain advisory opinions for a government Minister, who will make the final decision. Nonetheless, the Agreement makes it more difficult to

$84 \quad$ Platinex Inc $v$ Kitchenuhmaykoosib Inninuwug First Nation [2006] 4 CNLR 152 (Ont Sup Ct) paras 23-28. The trial judge's decision was overturned after the leaders of the First Nation had spent over two months in jail: Platinex Inc $v$ Kitchenuhmaykoosib Inninuwug First Nation [2008] OJ No 2650 (Ont CA).

85 For a general discussion, see Royal Commission, Report, above n 3, Vol 2 Pt 2 , 665-80. For American examples, see E Goodman, 'Protecting Habitat for Offreservation Tribal Hunting and Fishing Rights: Tribal Comanagement as a Reserved Right' (2000) 30 Environmental Law 279.

86 Agreement between the Inuit of the Nunavut Settlement Area and Her Majesty the Queen in Right of Canada (Minister of Indian Affairs and Northern Development and Tungavik, 1993) ('Nunavut Land Claims Agreement'). 
ignore the advice of the co-management board. The structured decisionmaking in the Nunavut Wildlife Management Board is illustrative. The Board is the main instrument for wildlife management in the Nunavut Settlement Area and the main regulator of access to wildlife. The purpose of the Board is to create a system of harvesting rights and, priorities and privileges that reflect current and traditional Inuit harvesting. When the Board makes a decision, it is to convey the decision privately to the Minister. If the Minister decides to reject the advice of the Board, the Minister must give his or her decision in writing within 30 days and permit the Board to reconsider its decision. The Board will then reconsider the matter and make its decision publicly. At that point, the Minister is again in a position to accept the decision of the Board or reject the decision of the Board. ${ }^{87}$

In some cases, however, the Boards have more significant authority. The Nunavut Impact Review Board is the environmental assessment agency for the Nunavut Settlement Area. The Board examines the impact of project proposals on the land, air and water, and on the people of the Nunavut Settlement Area. They rely on traditional Inuit knowledge and recognized scientific methods to assess and monitor the environmental, cultural and socioeconomic impacts of proposals. The Board determines whether project proposals should proceed to development and, if so, under what conditions. If the Board decides that a development proposal needs to be reviewed, the Minister is required to refer the matter to a federal environmental assessment panel for socioeconomic and ecosystem impacts. ${ }^{88}$

In Australia, there have been extensive negotiations over joint management of parks. The individual arrangements vary, but they all have two elements in common: Indigenous participation on a board that manages the park, and lease payments to the local Indigenous community. A typical agreement relates to the Uluru-Kata Tjuta National Park. The Anangu were granted title deeds to the park and they leased the land back to Parks Australia for 99 years. The lease agreement 'encourages the maintenance of Anangu tradition through protection of sacred sites and other areas of significance'. The Anangu are to have a majority on the Board of Management, receive annual rental payments, and benefit from

${ }_{88}^{87} \quad$ Ibid, art 5.

$88 \quad$ Ibid, art 12. 
training and employment opportunities. ${ }^{89}$ A similar initiative exists in Aotearoa/New Zealand, where there have been negotiations over three sacred mountains. Māori have been provided a role in the management of the mountains, although Jacinta Ruru feels it falls short of the type of comanagement that exists over some parks in Australia. ${ }^{90}$

The co-management or joint management arrangements can bring benefits to Indigenous people, but usually, the scope of their powers is so limited that they fall well short of recognizing Indigenous jurisdiction over their traditional lands.

\section{Participation in Public Government}

Two of the models that I have discussed so far, sovereignty and selfgovernment and self-administration, and self-management, involve the creation of institutions that are run by Indigenous people to serve Indigenous people. Self-determination could also take a direction that incorporates participation in the mainstream political system. There are three main variants to this model.

\section{GUARANTEED SEATS IN PARLIAMENT}

In 1867, New Zealand set aside four seats for Māori in the Parliament. Voters choose whether to be on the 'Māori roll' or on the general roll. Those who decide to be on the Māori roll vote for a representative in one of four Māori districts. In the 1996 elections, a partly Māori party, New Zealand First, took all the Māori seats. The Māori vote was diverse however, and there were fifteen members of Parliament representing a cross section of the political spectrum. ${ }^{91}$ Nonetheless, there have always

See Australian Department of the Environment, Water, Heritage and the Arts at www.environment.gov.au/parks/national-parks.html. Generally, see D Craig, 'Indigenous Joint Management of National Parks' [1999] Australian Indigenous Law Reporter 46, at www.austlii.edu.au/au/journals/AILR/1999/46.html. J Ruru, 'Indigenous Peoples' Ownership and Management of Mountains: The Aotearoa/New Zealand Experience' (2004) 3 Indigenous Law Journal 111. For a weak version of co-management over other natural resources, see the iwi management plans under the Resource Management Act 1991, at www.rmalink.org.nz/view-subprocess.php? $\mathrm{id}=21$.

Durie, above n 16, 98-110. 
been doubts about the extent to which the sitting members represented distinctly Māori i interests. This is because the mainstream political parties have ran candidates for the Māori seats so that the sitting members owed their first loyalty to the party, not to their constituents. The issue came to a head in 2004, when the Labour government enacted legislation that overturned a court decision and purported to extinguish Māori rights on the foreshore and seabed. The measures were strongly opposed by many Māori and there were marches against the legislation. The members sitting in the Māori seats were all members of the Labour party and they were told to vote with the government or face sanctions. One member decided to resign and went on to found the Māori Party. By the 2005 election, changes to the election laws resulted in seven Māori seats. The Māori Party took four of them, with the remaining three going to Labour. ${ }^{92}$

New Zealand is the only country with seats set aside for Indigenous voters. In Canada, the Electoral Reform Commission decided against this model and opted instead to recommend that electoral boundaries be adjusted to create ridings with higher concentrations of Aboriginal people. ${ }^{93}$ The federal government did not adopt this recommendation.

\section{PUBLIC GOVERNMENT}

In Canada's North, the Inuit of the Eastern Arctic succeeded in creating a new Territory called Nunavut. They have opted for a 'public government' model in which all residents of the territory, whether Inuit or not, may vote in territorial elections. Presently, the Inuit constitute a majority in this territory and therefore will have control. However, the government itself is structured as a territorial government exercising powers delegated by the federal government. This means that the Inuit will enjoy the full range of services and jurisdictions available to other territorial governments, but that they will also be bound by conventional institutional structures. ${ }^{94}$

The Inuit in Nunavut have protected their own rights in a separate Nunavut Land Claims Agreement that establishes their ownership to land and ice as well as harvesting rights. I have already described the co-

\footnotetext{
92 Elections New Zealand, at www.elections.org.nz.

93 RA Milen (ed), Aboriginal Peoples and Electoral Reform in Canada (Dundurn Press, 1991).

$94 \quad$ Nunavut Act (1993) c 28.
} 
management aspects of this agreement. What you have in the result, is a publicly elected territorial government that is largely Inuit, presiding over land that is partly under the mainstream regime and partly under a land claims agreement that preserves rights for Inuit. If the population balance shifts toward non-Inuit in the future, there may be danger of diluting the Inuit influence. On the other hand, this model may provide the means for an organic way to incorporate changing demographics.

\section{ELECTED INDIGENOUS PARLIAMENT}

The three Scandinavian countries have Parliaments for the Sami people. The Sami are Indigenous people who live in the northern parts of Finland, Sweden, Norway and Russia. They number 75,000-100,000. They have traditionally been associated with reindeer husbandry and it is still an important component for many Sami. The Parliaments were established first in Finland (1972), followed by Norway (1989) and Sweden (1993). Although they are called Parliaments, the number of elected members is small, consisting of 20-30 representatives. In Norway, the mainstream parties run candidates for the elections whereas in Sweden, there are Indigenous parties who put up candidates. These Parliaments do not have law-making power, but serve to advise government on issues of concern to Sami and have responsibility for some program funding.

The Scandinavian Parliaments have been criticized for being ineffective. In fact, the Royal Commission on Aboriginal Peoples flatly stated '[s]imply put, the Sami Parliaments lack clout'. ${ }^{95}$ The Royal Commission favoured the concept of a separate legislative body for Aboriginal peoples and recommended the establishment of a third chamber of Parliament called the House of First Peoples. Unlike the Scandinavian models, this chamber would have the ability to initiate legislation as well as providing 'advice to the House of Commons and the Senate on legislation and constitutional matters relating to Aboriginal peoples. $^{96}$

95 Royal Commission, Report, above n 3, 378. For an article on possible reforms, see AJ Semb, 'Sami Self-determination in the Making?' (2005) 11 Nations and Nationalism 531.

96 See recommendations 2.3.51-2.3.54 in Royal Commission, Report, above n 3, Vol 2, Pt 1, 377-82. 


\section{PROCESS FOR IMPLEMENTATION}

Up to this point, we have discussed self-determination mostly in the context of the relationship between an Indigenous community and the nation-state in which they live. We have looked at how the models differ, depending on the degree to which the Indigenous community can act independently of state legislation. In this section, I will touch on issues that are important internally for the Indigenous community itself: the process for implementation; what constitutes the community; what accountability mechanisms will control the Indigenous authority; and the importance of addressing the interests of women. The settler governments have a role in ensuring a smooth transition toward the exercise of greater self-determination in all these areas, but must act in a way that respects the autonomy of the community.

\section{A. COMMUNITY-BASED PROCESS}

One thing that must be clear from earlier chapters of this reader is that imposed solutions concocted by non- Indigenous social engineers will not work. Even the most well-meaning individuals can trigger disastrous social consequences. The only sensible process is one that involves the Indigenous community in the conceptualization, design and execution of the initiative. It is important for the community to be given the space and time to identify its needs, its priorities and the way in which it wishes to proceed. The proposals put forward by the community may not fit neatly into the bureaucratic boxes created by government departments. But that is the challenge that progressive governments must take up. ${ }^{97}$

When I worked for the Ministry of the Attorney General, we funded a community justice initiative on an Indian reserve. Some months into the project, the reserve justice committee heard from teachers that children from a particular family were arriving hungry at school. Rather than sanctioning the parents or apprehending the children, the justice committee decided to run a bingo to raise money for a lunch program for all of the children in this school. This caused some consternation within the Ministry because it appeared that the justice project had become

97 Imai, Handbook, above n 18, 181-85. 
involved in areas that should perhaps be in the domain of the Ministry of Family Services or the Ministry of Education. Some bureaucrats wondered whether the Ministry of the Attorney General should continue funding the program. This may seem like a trivial issue but it is real, as anyone who has worked in government can attest, and the internal bureaucratic dynamics can have devastating impacts on projects on the ground.

For lawyers, especially, the importance of understanding a community-based approach is crucial. Law students are generally given the impression that law is a system of rules and the role of lawyers is to apply those rules with as much precision as possible. The focus is on the rule and what courts or legislatures have said about the rule. But in working with Indigenous communities, the rule-based focus can lead to bizarre results, such as the fight over the provincial-federal boundary in the story that opened this chapter. In the community lawyering approach, the focus is on how law interacts with the community as a whole. Christina Zuni Cruz makes the connection between community lawyering and self-determination in her work with the Isleta Pueblo:

Successful community lawyering has just as much to do with process as it does with outcome, and when one values community, process becomes critical. Process is critical because for native peoples, community lawyering is about self-determination, both for the community and the individual, about recognizing traditional norms and practices, and about valuing relationships. ${ }^{98}$

\section{B. WHO IS THE ‘COMMUNITY’ OR THE 'NATION'?}

Forced migration, urbanization and internal social dynamics have splintered Indigenous communities in many ways so that today, many do not conform to historical or 'traditional' groupings. For government, it is sometimes difficult to know who represents what constituency. For

C Zuni Cruz, '[On the] Road Back In: Community Lawyering in Indigenous Communities' (1999) 5 Clinical Law Review 557, 563. See also S Imai, 'A Counter-Pedagogy for Social Justice: Core Skills for Community-based Lawyering' (2002) 9 Clinical Law Review 195. 
communities there is a danger that a purported 'leader' may not be mandated to speak for that community.

The New Zealand Law Commission has addressed this issue in its report, Waka Umanga: A Proposed Law for Maori Governance. ${ }^{99}$ The two main political units among Māori are the hapu (tribe) and iwi (tribal confederation), but there are also many urban Māori who do not identify with any particular iwi. The law has recognized that Māori collectivities have interests in communal assets, but the legal or social personality of the group holding those assets is not clear. Māori collectivities had been using a variety of existing vehicles, such as corporations and trusts, in order to interact with the mainstream legal system but these vehicles were an awkward fit. In order to provide more certainty in this area, both for the government and for the Māori themselves, the Commission recommended creating a special corporate vehicle called the waka umanga, which would have some of the characteristics of a corporation but which would leave most of the internal arrangements to a charter developed by the Māori collectivity. It is interesting to see the approach the Law Commission has taken to determine how the waka umanga would be established. They regarded the hapu as the basic unit and suggested that there should be at least fifty members for the group to be viable.

... A viable hapu being one that can respectably manage customary requirements in welcoming, feeding and bedding other tribal groups. That probably requires an active and local membership of at least 50, as nowadays all are not available for every event. ${ }^{100}$

The Law Commission recommended that fifteen people could propose or oppose the creation of a waka umanga and that disputes can be taken to the Māori Land Court, which has expertise on Māori issues. Initially, those that get together to make or oppose the waka umanga determine the membership of the group. Outside of the requirement for the minimum size of a hapu, there are no imposed criteria. The Law Commission stated

\footnotetext{
99 New Zealand Law Commission (NZLC), Waka Umanga: A Proposed Law for Maori Governance Entities, Report 92 (NZLC, May 2006) at www.lawcom.govt.nz. Ibid, para 7.65 .
} 
that 'it is the right of a tribe to determine its own membership and membership rules'. ${ }^{101}$

The Canadian Royal Commission on Aboriginal Peoples also turned its mind to the process for the creation of nations that would have a land base and self-governing jurisdiction. In order to move toward a model that was closer to the American situation, Canada's six hundred or so Bands created under the Indian Act would need to be reconstituted as larger nations based on traditional affiliations numbering 50-80. ${ }^{102}$ These larger nations would hold the inherent right to self-government. The Commission suggested that a charter group, a group of Bands currently recognized under the Indian Act, for example, would hold a referendum to determine whether to proceed toward self-government. This group would then develop a constitution and membership criteria that were inclusive of those historically excluded by the membership criteria of the Indian Act. Membership would not depend on blood quantum. It is contemplated that there would be wide consultation with the larger membership. In order to be recognized the constitution and membership criteria would be presented to a Recognition Panel, composed of a majority of Aboriginal people. ${ }^{103}$

The flexibility suggested by the New Zealand and Canadian reports is important. Stephen Cornell says:

the best way to avoid the one-size-fits-all recipe for failure is to let Indigenous peoples decide for themselves who the appropriate self in self-governance is and how selfgoverning institutions should be structured-and to accept the variety of relationships and governance solutions that will surely result. This is what self-determination means. Furthermore, not only is outsider decision-making in this regard the antithesis of self-determination, but neither collective units nor governing institutions that are imposed by outside authorities are likely to command the respect or allegiance of the peoples on whom they are imposedwhich means they will not work. ${ }^{104}$

\footnotetext{
$101 \quad$ Ibid, para 4.50 .

102 Royal Commission, Report, above n 3, Vol 2, Pt 2, 181.

103 Ibid, 314-20.

104 Cornell, above n 13, 27.
} 


\section{ACCOUnTABILITY OF INDIGENOUS GOVERNMENT AND THE ROLE OF COURTS}

There is some controversy on how to ensure that an Indigenous governing body should be made accountable to its own citizens and how it should adhere to human rights standards. Some Indigenous leaders have expressed concern that merely applying civil liberties law from the common law systems would import a set of criteria based on western individualistic values that are incompatible with Indigenous forms of organization. ${ }^{105}$ For example, the importance of collectivity and communal ownership of land for Indigenous people would be different from the concepts of private property enshrined in the American Bill of Rights. It has been noted earlier that United States Congress enacted the 'Indian Bill of Rights' in the Indian Civil Rights Act because the Bill of Rights in the American constitution did not apply to the tribes. The enactment of this statute was not universally welcome. Domingo Montoya, a Pueblo leader, wanted to be exempt from its application, saying '[o]ur deep concern over the Indian Bill of Rights stems from our fear that it will destroy the traditions - and in doing so greatly weaken our governments'. ${ }^{106}$ Nonetheless, in every jurisdiction, there are imposed limits on Indigenous governments. Every self government agreement in Canada states that the Charter of Rights and Freedoms applies to that Aboriginal government, although there are provisions for ensuring that the impact is softened where the application of individual rights would derogate from Aboriginal or treaty rights. ${ }^{107}$

105 ME Turpel, 'Aboriginal Peoples and the Canadian Charter: Interpretive Monopolies, Cultural Differences' (1989-90) 6 Canadian Human Rights Year Book 3. For a discussion of the impact of the Indian Civil Rights Act, see K McNeil, 'Aboriginal Governments and the Charter: Lessons from the United States' (2002) 17 Canadian Journal of Law and Society 73.

106 Quoted in J Wunder, Retained by the People (Oxford University Press, 1994) 149.

Constitution Act 1982, s 25 reads, in part: '[t]he guarantee in this Charter of certain rights and freedoms shall not be construed so as to abrogate or derogate from any aboriginal treaty or other rights or freedoms that pertain to the aboriginal peoples of Canada...' 
The courts will have an important role to play in the application of individual rights standards to Indigenous governments. In this task, the courts should be sensitive to balancing the interests of individual Indigenous citizens against the importance of the integrity of the Indigenous government and the reality of the context of Indigenous communities. The courts in the United States used the Indian Bill of Rights to make very interventionist decisions in the first five years after its enactment, but have since pulled back to give greater rein to Indigenous sovereignty. ${ }^{108}$ Undoubtedly, the task of resolving disputes within an Indigenous community can be challenging for judges. While a mechanical application of rules established in the common law would yield some sort of a result, it might not be a result that would be appropriate for the community. In Canada, Federal Court judges have been developing jurisprudence on disputes arising from customary selection of Indian Band leaders. The codes for these elections are created by the Bands themselves and the procedures for their adoption are often contentious, as disputes arise around decision-making 'traditions' or 'customs'. The judges have adapted some general administrative law principles, such as bias and procedural fairness, taking into account the small size of the communities. For example, the strict application of 'conflict of interest' does not make sense when there are so many people related to each other. ${ }^{109}$

\section{THE ROLE OF WOMEN}

Gender relations in Indigenous communities have been greatly influenced by gender relations in the larger settler communities. Consequently, during the time when white women had few rights, the same regime was enforced, directly or indirectly in Indigenous communities. In Canada, for example, the Indian Act reflected patriarchal attitudes of the nineteenth century when women lost much of their independence on marriage. White women who married Indian men became Indians. On the other hand, Indian women who married white men, lost their status as Indians. When women in the settler society began asserting equality rights in the sixties

\footnotetext{
108 Wunder, above n 106, 148-56.

109 For summaries of court cases on custom elections, see the annotations to s 2(1) 'council of the band' in the annual volumes of S Imai, Annotated Indian Act and Aboriginal Constitutional Provisions (Carswell, 2009).
} 
and seventies, the same occurred in Indigenous communities. Canadian Indian women waged a successful campaign to repeal the offending provisions of the Indian Act in $1985 .{ }^{110}$

The right of women to membership is controversial because it can run up against the very self-determination right that is being advocated here. The issue is illustrated in the case of Santa Clara Pueblo $v$ Martinez. ${ }^{111}$ The Pueblo tribal law set out that the children of a woman who married out of the tribe lost their tribal membership. In this case, a Pueblo woman married a Navajo man and the family continued to live on the reserve. The mother and a child challenged the law as discriminatory under the Indian Civil Rights Act because the children of men who married out of the tribe retained Pueblo membership. The US Supreme Court held that federal courts lacked jurisdiction to deal with claims under this statute because, imprisonment aside, enforcement of the statute was a tribal matter. Author John Wunder hails this decision as an affirmation of tribal sovereignty. ${ }^{112}$ Others see this as toleration of sexism within tribal communities. ${ }^{11}$

One way to address concerns about discrimination against women has been to ensure that settler government documents impose gender equality. The Law Commission report from New Zealand has addressed the gender issue directly suggesting that, while the right to decide membership is to be respected, gender discrimination in the waka umanga should not be permitted. ${ }^{114}$ In Canada, the Constitution Act, 1982 states that Aboriginal and treaty rights are 'guaranteed equally to male and female persons'. ${ }^{115}$ Another way to address the concern is to ensure that, in any transitional period toward new structures or new initiatives, the interests of women are taken into account in the process. The Royal

110 J Silman, Enough is Enough: Aboriginal Women Speak Out (The Women's Press, 1987) for interviews with the women who led the fight. Although the amendments to the Indian Act allowed women who lost their status to be reinstated, there is still discrimination against women built into the new scheme: Royal Commission, Report, above n 3, Vol 4, 37-53. For a general commentary from a Mohawk perspective, see P Monture-Angus, Thunder in My Soul: A Mohawk Woman Speaks (Fernwood Publishing, 1995).

$111 \quad$ Santa Clara Pueblo v Martinez, 436 US 49 (1978).

Wunder, above n 106, 153-56.

For a summary of critiques of this decision from the perspectives of women, see Getches, et al, above n 31, 399-405.

Waka Umanga, above n 98, para 4.53.

Constitution Act 1982, s 35(4). 
Commission on Aboriginal Peoples recommends that all nations 'ensure that the participation of women in the creation and design of justice systems is both meaningful and significant ${ }^{116}$

In the end, we must realize that establishing abstract legal standards or creating inclusive processes do not, by themselves, ensure the protection of women. There must be a meaningful way, on the ground, to implement solutions that are effective. The opening story in this chapter showed how a conflict between the federal and provincial government stymied attempts by the community to control alcohol abuse. In the United States, a jurisdictional conflict affects women who experience domestic violence on tribal lands. Statistics reveal that Indian women experience very high rates of spousal abuse -39 per cent have been victims. NonIndian men commit 75 per cent of the abuses. As we have mentioned, Indian tribal courts do not have jurisdiction over non-Indians, so they are left powerless. The federal government, which does have jurisdiction, has not committed funds to enforce federal laws on Indian reserves. Only 30 per cent of all federal crimes on tribal land were prosecuted by federal attorneys and within that number, domestic assaults are a low priority. Rebecca Hart and Alexander Lowther argue that the solution lies in placing greater authority in the hands of the tribes: '[t]ribal remedies not only bolster the sovereignty of tribes, they aid Native American women in reclaiming self-determination over their bodies'. ${ }^{117}$

\section{CONCLUSION}

In this chapter we have reviewed a number of forms of governance that could result from the exercise of self-determination. Outright independence apart, the form that gives the greatest autonomy from the settler government is the United States model where courts have recognized tribes as 'domestic dependent nations'. Under the doctrine of

116 Royal Commission on Aboriginal Peoples, Bridging the Cultural Divide: Aboriginal People and Criminal Justice in Canada (Canada Communications Group, 1996) 275.

117

RA Hart and MA Lowther, 'Honoring Sovereignty: Aiding Tribal Efforts to Protect Native American Women from Domestic Violence' (2008) 96 California Law Review 185. 
retained sovereignty, tribes generally have power to make laws in all areas until they have been overridden by an Act of Congress. In Canada, the recently negotiated self-government agreements, such as the Nisga'a Agreement recognize that First Nations have an inherent right of selfgovernment. Although the scope of Nisga'a powers is more limited than the powers of tribes in the United States, the laws that the Nisga'a can make in relation to some matters are paramount over federal and provincial laws. Unlike in the United States, the Nisga'a law making authority is constitutionally protected so that unilateral federal legislation cannot take away those powers.

Self-administration and self-management models are found in all four jurisdictions. Indigenous nations receive delegated responsibilities from federal or state governments to administer services to their constituents. The most advanced form of this model is found in Canada under the Indian Act. Indian Bands have reserves set aside and some power to make local by-laws. Land settlements in Australia and New Zealand have given limited by-law making authority to Indigenous bodies. Where there is no land base, the most elaborate model was the Aboriginal and Torres Straight Island Commission in Australia, which had nationally elected Aboriginal representatives on its board, and its mandate included advocating for the interests of the Indigenous people. This model for service delivery has advantages, especially for Indigenous people living in urban areas. However, it has been criticized for being too dependent on non- Indigenous design and implementation, to be entirely satisfactory.

Ownership and control of lands and resources is crucial to the survival of Indigenous peoples. Some Indigenous communities and nations do own some resources, especially where there is a recognized land base. But ownership is not the only issue. Indigenous control and participation in the stewardship of the resource is also important, and this is most often accomplished through co-management or joint management structures.

Finally, we have reviewed variations on participation in public government. In Aotearoa/New Zealand, the reserved seats for Māori have been a feature of their legislature since 1867. Recently, Inuit of Nunavut have opted for a public government model combined with reserved rights set out in a land claims agreement for Inuit. Institutions similar to Sami Parliaments in Scandinavia have not picked up many adherents in the four countries studied in this reader.

It is difficult, in the abstract, to judge which is the 'best' model. They all have limitations and advantages for certain constituents. It is 
important to note, however, that a judgment cannot be made simply on whether the institutions or activities "look Indigenous". Indigeneity, like non-indigeneity, changes over time. To understand a society, it is not appropriate to take a snapshot that freezes relationships and movement at a particular moment in history. It is more appropriate to think of a video camera that captures shifting patterns, motion, and temporal texture. Indigenous people interacting with the non- Indigenous world are constantly defining Indigeneity, so it is difficult to 'fix' on a particular set of characteristics.

Rather than focusing on outward appearances, it may be more useful to think of criteria that reflect the dynamic nature of Indigenous communities and their relationship with the state. I believe that there are at least three factors to consider in the evaluation of particular choices for self-determination. The first would be to determine the degree to which the Indigenous group participated and consented to the arrangement. I have indicated that wide participation at a community level, including the active participation of women in the decision-making process is crucial to success. Second, the arrangement could be judged on the degree to which the Indigenous people have autonomy to conceptualize, design and implement their priorities. For example, laws that may work perfectly well within the mainstream society may not be appropriate in the Indigenous context. Third, the initiatives adopted should ensure transparency and accountability within the Indigenous community. This will require a careful balancing between respecting the autonomy of the Indigenous collectivity and ensuring that individuals within that collectivity are treated equitably. To continue the development of Indigenous selfdetermination, then, would involve increased participation, increased autonomy and increased Indigenous government accountability.

The road ahead is not clear by any means. While there have been some advances in government policies through court decisions, there have also been significant setbacks. In Australia, the recommendation for a national treaty was rejected by the government of the day and the only nationally elected representative organization for Indigenous people, the Aboriginal and Torres Straight Islander Commission, was disbanded in 2005. In Canada, there has been very little follow up by governments on the recommendations of the Royal Commission on Aboriginal Peoples. ${ }^{118}$

118 Assembly of First Nations (AFN), Royal Commission on Aboriginal People at Ten Years: A Report Card (AFN, no date); D Stack, 'Making Aboriginal Policy: 
New Zealand enacted the Foreshore and Seabed Act 2004 to vest title in the Crown in order to overturn a court decision that had looked favourably on Māori interests. ${ }^{119}$ The US Supreme Court has backtracked on sovereignty rights and has severely curtailed jurisdiction of tribes over non-Indians. ${ }^{120}$ On the international front, it is important to note that the only four countries to vote against the Declaration on the Rights of Indigenous Peoples at the United Nations General Assembly in 2007 were Australia, Canada, New Zealand and the United States.

History so far has taught us two things. First, Indigenous people are not going to disappear. Second, the assimilation policies have been a dismal failure. Studies, such as that of Chandler that relate selfdetermination to lower suicide rates, and that of the Harvard Project on American Indian Economic Development, that relate self-determination to greater economic stability, should impel governments to recognize that self-determination for Indigenous peoples is the only viable policy for the years ahead.

A Conference Ten Years After the Final Report of the Royal Commission on Aboriginal Peoples The First Decade of RCAP's Influence on Aboriginal Law' (2007) 70 Saskatchewan Law Review 123.

119 See the chapter in this book by Jacinta Ruru.

120 See the chapter in this book by Benjamin J Richardson. 